\title{
Gender as a Moderator of the Relationship between OCB and Turnover Intention
}

\author{
Shaiful Annuar Khalid \\ Faculty of Business Management, Universiti Teknologi Mara (UiTM) \\ 02600, Arau, Perlis, Malaysia \\ Tel:60-12-514-0436Ｅ-mail:shaiful@perlis.uitm.edu.my \\ Hj.Kamaruzaman Jusoff (Corresponding author) \\ Faculty of ForestryUniversiti Putra Malaysia \\ 43400, Serdang, Selangor Malaysia
}

Tel: 60-3-8964-7176 E-mail: kjusoff@yahoo.com

Hassan Ali

Faculty of Business Management, Universiti Utara Malaysia

06010 Sintok, Kedah, Malaysia

Tel: 60-19-454-1162Ｅ-mail:hassan@uum.edu.my

Mohammad Ismail

Faculty of Business Management, Universiti Teknologi Mara (UiTM)

02600, Arau, Perlis, Malaysia

Tel: 60-4-986-1001Ｅ-mail: mohammadismail@perlis.uitm.edu.my

Kamsol Mohamed Kassim

Faculty of Business Management, Universiti Teknologi Mara (UiTM)

02600, Arau, Perlis, Malaysia

Tel: 60-19-550-5432Ｅ-mail:Kamsol@perlis.uitm.edu.my

Norshimah Abdul Rahman

Faculty of Business Management,Universiti Teknologi Mara (UiTM)

02600, Arau, Perlis, Malaysia

Tel: 60-4-986-1001Ｅ-mail:shima70@perlis.uitm.edu.my

\begin{abstract}
This paper examines the relationship between OCBs and turnover intention. The sample consisted of 557 non manager employees across 63 hotels in Malaysia. Managers' ratings of employees' OCBs were collected and matched with 557 employees' self ratings of turnover intention and demographic. Factor analysis of OCB items revealed a new dimension of OCB, labeled as patience, together with four common dimensions - helping behavior, conscientiousness, sportsmanship and civic virtue. Consistent with cognitive consistency theory, the results show that helping behavior,
\end{abstract}


conscientiousness, patience and civic virtue were significantly and negatively related to turnover intention. Moreover, the OCB dimensions explained a meaningful portion $(25 \%)$ of the turnover intention measure. The results indicated that gender moderated the relationship between helping behavior and turnover intention and this relationship was stronger for females than males. These results point to the importance of considering behavioral factors in effort to predict and manage employee turnover.

\section{Keywords: Organizational citizenship behavior, Turnover intentions, Hotels, Gender}

\section{Introduction}

Due to the assumption that organizational citizenship behavior (OCB) enhances teams and organization effectiveness (Organ, 1988; Bateman \& Organ, 1983; Podsakoff, Ahearne, \& MacKenzie, 1997), antecedents of OCB have been the focus of substantial research attention. Although we have gained a substantial understanding of the underlying reasons for OCB, significantly less research effort has been given in estimating the effects of OCB on organizational effectiveness or some other measures of organizational effectiveness such as employee turnover. This situation represents one of the empirical gaps in the current OCB literature. Although over 160 studies have been reported in the literature to identify the factors influencing OCB, only a few studies have attempted to investigate whether these human behaviors contribute to organizational effectiveness (Podsakoff, Mackenzie, Paine and Bachrach, 2000; Peloza, Hudson and Hassay, 2009). For example, Peloza et al., (2009) state that employee volunteerism can be an effective strategy for increasing the value of corporate philanthropy. Likewise, review of the current literature revealed that studies investigating the effects of OCB such as on employee turnover are relatively sparse. To our knowledge, only a few studies have explored the relationship between OCB and employee turnover (e.g., Chen, Hui \& Sego, 1998). Limited research of this nature conducted to date does not permit much generalization thereby warranting further exploration and validation of the research findings. A reason for looking at turnover outcome is that turnover is also a criteria for organizational achievement or regarded as surrogate of organizational effectiveness (Angle \& Perry, 1981). Turnover describes lasting removal, voluntarily or involuntarily, of an employee from the organization. Voluntary turnover is considered the most detrimental as it usually takes the organization by surprise (Boshoff \& Mels, 2000). Ample evidence shows that employee turnover influences hotel performance. Turnover increases separation costs, replacement costs and training costs (Koys, 2003). A great number of researches have been conducted to understand factors contributing to turnover. Despite over 1500 studies in the turnover literature (Shaw, John, Jenkins \& Nina, 1998), previous research on this dysfunctional behavior have focused on such antecedents as job satisfaction, commitment, cognitive process and demographic factors and have not paid much attention to the role of behavioral antecedents. The nature and types of turnover have been described elsewhere. Turnover intention is the focus of this study. Koh and Goh (1995) stated that turnover intention is under employees control to a greater extent as compared to actual turnover. Moreover, the best predictor of behavior (e.g., actual turnover) is behavioural intention (Ajzen \& Fishbein, 1980).

The objectives of this study are to: (1) investigate the effects of OCBs on turnover intention of non manager employees in hotel industry and (2) examine the moderating effect of gender on the relationship between OCBs and turnover intention. The knowledge of OCB dimensions affecting or not affecting turnover intention can help hotels manage employee turnover intention better by focusing on the critical OCB elements.

\section{Literature Review}

\section{$2.1 O C B$ and Turnover Intention}

OCB refers to extra role behaviors exhibited by employees that are discretionary and go beyond formal task obligation. OCB is more of a matter of individual option and may not be officially required of employees. Organ (1988) defines OCB as: "individual behavior that is discretionary, not directly or explicitly recognized by the formal reward system, and that in the aggregate promotes effective functioning of the organization." (p. 4). A good citizen is an employee who offers support to the organization, even when such support is not verbally demanded (Moorman \& Blakely, 1995). Even though, there is no clear agreement within the literature on the number of OCB dimensions, there are five categories of OCB that are commonly identified and examined in research which are altruism, conscientiousness, sportsmanship, courtesy and civic virtue (LePine, Erez \& Johnson, 2002). Why OCB should be related to employee turnover? To better understand these effects, we must examine the nature of OCB and turnover. Since the practice of citizenship behavior is optional, a good organizational citizen can be considered as an all-around contributor - the ones who are not only good in accomplishing formal duties but also assist those around them by helping others, being good sport or exhibiting high levels of civic virtue and conscientiousness. Moreover, an active behavioral participation in a social group (e.g., helping co-workers and supervisors, always willing to cooperate or tolerating inconvenience at work) should also reflect the employees' constructive attitudes in various aspects and a strong organizational attachment. On the other hand, withdrawal behavior such as employee turnover is regarded as detrimental or dysfunctional (Pelted \& Xin, 1999) and is potentially destructive to one's coworker, work group and organization. Since, OCB reflects voluntary behavior that is beneficial to organization, whereas withdrawal behavior is considered as resentment toward the organization, we would expect that OCB and withdrawal behavior to be adversely related consistent with the cognitive consistency theory. 
Cognitive consistency theory claims that individuals are inclined to experience psychological discomfort when they behave in ways incoherent with their values and moral standard (Shengming \& Jiping, 1997). Peoples are motivated to act congruent with their beliefs and values or maintain agreement between their behaviors, beliefs and attitudes. When an individual decides on something or forms an attitude, the person then tends to behave in line with the formulated attitude (Coon, 1983). In applying cognitive consistency theory, we proposed that employees' OCB are systematically related to the subsequent turnover intention. Specifically, as an individual's OCB at work decreases, that individual's tendency to withdraw from job will increase. Although other factors should also influence turnover, it is likely that employees with higher levels of OCB would then report lower levels of turnover intention so as to preserve linkages to the organization. Moreover, Chen et al., (1998) indicated that OCB reflects employees' readiness to be actively involved in or to be part of the organization. Levels of OCB imply the space an employee would like to keep between him or her and the organization. Given the relative support for cognitive consistency theory across a variety of situations (see, for example, Ward, 1986; Green \& Holeman, 2004; Faulkner \& Reeves, 2000), it is predicted that this theory would provide a support for the OCB and employee turnover intention linkages. Empirically, Chen et al., (1998) confirmed that levels of altruism, conscientiousness and sportsmanship were higher among employees with no turnover than among employees who left the organization.

Based on the above-mentioned studies and theoretical discussion we can reckon that OCB might have an influence on employees' turnover intention.

\subsection{Gender as a Moderator}

A number of previous studies have investigated the relationship between gender and turnover intention. It has been suggested that females are more likely to turnover because they have more sporadic work histories, lower tenure and lower pay (Arnold \& Feldman, 1982) and weak attachments to their job (Chaudhury \& Ng, 1992). Studies by Cotton and Tuttle (1986) and Weisberg and Kirschenbaum (1986) found that females were more likely than males to quit. The relationship between gender and OCB, however, has not been given much attention in previous studies. Lovel, Aston, Mason and Davidson (1999) stated that elements of OCB such as kind, understanding, devote self to others, and supportive to others are congruent with feminine behaviors. In the context of working environment, women favored job attributes that offer interpersonal orientation which include opportunities to work with others, making friends, and kindness (Konrad, Ritchie, Lieb \& Corrigall, 2000). Theory of prescriptive stereotypes, does advocate that women have higher collective attributes than men and these differences reflect how social roles of women and men differ (Eagly, 1987). Most articles in OCB, however, did not report a gender analysis (Kidder \& Parks, 2001). A limited study has documented empirical support that women have higher level of altruism and helping behavior than men (e.g., Lovel et al., 1999; Morrison, 1994).

Given the above, we propose that gender will moderate the relationship between OCB and turnover intention.

\section{Methodology}

\subsection{Sample}

This study was carried out among a sample of non-manager employees drawn from 63 different hotel properties in the northern region of Peninsular Malaysia. There were 834 pairs of subordinate questionnaires and manager questionnaires distributed within the period of five months from January to May 2004. These questionnaires were administered and collected with the help of human resources departments of each hotel. List of employees name and their manager were obtained for the purpose of coding the two sets of questionnaires. The name of employees were placed on the manager questionnaires for OCB evaluation and a code number representing each employee was placed on each employee questionnaires for self ratings of turnover intention and demographic information. Analysis related to the hypothesis required the matching of manager's responses with specific subordinates. In some cases, manager ratings were obtained but subordinates responses were not obtained. In other instances, subordinates responses were obtained but no manager ratings to match. Thus usable sample for correlating variables could not include all managers and subordinates responses. A total of 624(74.8\%) subordinate questionnaires and 631(75.7\%) manager questionnaires were returned respectively. Thirty six subordinates did not receive ratings from manager, and they were excluded from the analysis and 43 manager questionnaires without the subordinate responses to match were also excluded, resulting in 588 matched subordinates-manager cases. After deleting incomplete responses, a total of 557 subordinates-manager cases were available which covered a broad range of non manager occupations. Fifty-five percent of the respondents indicated that they were male and $45 \%$ identified themselves as female. In term of ethnicity, $77 \%$ indicated they were Malays, $13 \%$ Chinese, $8 \%$ Indian and 2\% others. Respondents ranged in age from 18 to 56 years with a mean of 29 years. The average employees had been with the hotels for 4 years. In term of marital status, $50 \%$ of the respondents were married, $48 \%$ were single, $2 \%$ were widowed and the remaining $1 \%$ was others. In total, 287 managers or heads of department were involved in the evaluation of their respective employees' levels of OCB. In the present study, managers rated between one to five employees each but the majority rated only two employees. 


\subsection{Measurement}

A five dimensions scale developed by Podsakoff and Mackenzie (as cited in Niehoff and Moorman, 1993) was used in the present study. Managers were asked to indicate the extent to which their subordinates typically demonstrated the various citizenship behaviors at work using a 5-point Likert scale format from (1) strongly disagree to (5) strongly agree. A sportsmanship item "Constantly talk about wanting to quit my job" is dropped since this item overlapped with an item measuring turnover intention - "I often think of leaving the organization" and replaced by an item from Podsakoff and Mackenzie (1994) that is "Always find fault with what the organization is doing". Overall, there are 42 items measuring OCB; 20 items adapted from Podsakoff and Mackenzie (as cited in Niehoff and Moorman 1993) and 22 new items. The new items were generated in an effort to capture broader citizenship behaviors among hotel employees. Initially 26 new items were generated based on Organ (1988) conceptualization of OCB and presented to several hotel human resource officers as well as hotel managers to make sure that the items capture those behaviors that are not part of employees' formal job description but are considered important for hotels organizational functioning. After discussions, 4 items were deleted because from the view points of hotel management, those items were not applicable across job levels and not considered as extra role. Minor modification was made to the questionnaire to suit with study sample. The words "organization" and "company" were replaced by the word "hotels".

Turnover intention was measured with 3 items adapted from Camman, Fichman, Jenkins and Klesh (as cited in Chen et al., 1998). The reported internal consistency coefficient for this scale was .78. The items are: (1) If I may choose again, I will choose to work for the current organization (reversed coded), (2) It is very possible that I will look for a new job within the next year and (3) I often think of leaving the hotel'. Respondents rated their level of agreement with each item on a 5-point scale with anchors strongly disagree and strongly agree. The three items were averaged to form a single scale for the subjective measure of turnover intention. Although each respondent possessed English ability to some extent, the entire instrument was translated into Malay using back translation method, and respondents were given both English and Malay versions to facilitate comprehension of the items.

\section{Data Analysis and Results}

Data analysis in this study was performed using SPSS computer package. Three cases were identified as multivariate outliers. These outliers when removed from the analysis did not affect the results and so were retained. Evaluation of assumption of linearity, normality and homogeneity of variance revealed no treat to multivariate analysis.

Principal components factor analysis using varimax rotation was conducted on the initial 42 items to determine which items grouped to form dimensions. There is a widespread use of component analysis which is suitable if the number of variables exceeds 30. Furthermore, varimax rotation seems to give a clearer separation of factors (Hair, Anderson, Tatham \& Black, 1998). Twelve items were deleted because of low communalities and some of these items loaded significantly on two factors. These analyses resulted in a five-factor solution with 3 to 14 items loading on each dimension. The results of this analysis are outlined in Table 1 . The five factors derived were clearly defined and highly interpretable, except for the lack of courtesy and altruism factors. The first factor consisted of 14 items (seven altruism items, six courtesy items and one civic virtue item). It is worth noting that, previous research have not been able to consistently recognize some of the finer distinctions between altruism and courtesy and tending to lump these into one broad helping construct (Podsakoff \& Mackenzie, 1994). Accordingly, in the present study, the first factor was labelled helping behaviour. Nine items loaded on factor two and factor four and the majority of these items were the sportsmanship items. Of the six items loaded on factor two, four of these items were sportsmanship items together with one courtesy item and one conscientiousness item. The four sportsmanship items loaded on factor two were those items adapted from Podsakoff and Mackenzie (as cited in Niehoff and Moorman, 1993). For reason of consistency with the previous research, the label of sportsmanship is used for factor two. The three newly developed items initially tended to measure sportsmanship loaded on factor four. It was felt that these three items reflect the employees' ability to persevere with something inconvenience or hardship at the work place. This factor was labelled patience. Four conscientiousness items loaded on factor three. Three civic virtue items loaded on factor five. Among the five dimensions of OCB derived from factor analysis, helping behavior is considered as individual-oriented OCB or OCBI, whereas, sportsmanship, conscientiousness, patience and civic virtue are considered as organizational oriented-OCB or OCBO. The responses were summed to form a single score of OCB as well as an index for each dimension.

\section{INSERT TABLE 1}

Internal consistency estimates and zero-order correlations among the continuous study variables were calculated and can be found in Table 2. The pattern of correlation is about what would be expected based on the literature. The intercorrelation was also inspected for multicollinearity. All correlation coefficient between manager ratings of OCB dimensions were below .70, therefore variable redundancy did not appear to be of concern (Nunnally, 1978). As can be seen, turnover intention was significantly correlated with all the five OCB dimensions as well as the OCB composite score. More importantly, the relationships were in the direction predicted by the study hypothesis. The strength of the relationship ranged from -.23 to -.43 . Sportsmanship $(\mathrm{r}=-.42, \mathrm{p}<.01)$ and patience $(\mathrm{r}=-.43, \mathrm{p}<.01)$ were significantly 
more highly correlated with turnover intention. Gender did not significantly correlate with OCBs and turnover intention. INSERT TABLE 2

To test the main effects of OCB domains, gender and the five interactions terms, we performed a stepwise multiple regression analysis (Table 3). First, we entered the main effect of OCB dimensions and then the moderator. Finally, we entered interaction terms between the five OCB dimensions and gender. A significant interaction term would be taken as an indication of a moderating effect. In order to reduce the multicollinearity associated with the use of interaction terms, the independent variables were centered before interaction terms were created (Aiken \& West, 1991). As can be seen in Table 3, OCB dimensions which were entered in the first step, explained a highly significant $(p<.001) 25 \%$ of the variance in turnover intention. Consistent with theoretical expectations, helping behavior $(\beta=-.21, p<.01)$, sportsmanship $(\beta=-.31, \mathrm{p}<.01)$, patience $(\beta=-.28, \mathrm{p}<.01)$ and civic virtue $(\beta=-.15, \mathrm{p}<.01)$ are related to turnover intention. However, conscientiousness was not significantly related to turnover intention $(\beta=-.05, \mathrm{n} . \mathrm{s})$. The demographic variable of gender, entered in the second step, did not account for a significant incremental change in R-square. The five interaction terms, entered in the third step increased explained variance by a significant $8 \%(p<.05)$, although only helping behavior $\mathrm{x}$ gender $(\beta=.12, \mathrm{p}<.05)$ was responsible for the incremental change.

INSERT TABLE 3

The significant interaction is depicted in Figure 1, in which helping behavior and turnover intention relationship is plotted separately for females $(\mathrm{n}=250)$ and males $(\mathrm{n}=307)$ with low and high helping behavior. Group membership was assigned by median split on the helping behavior index $(\mathrm{Mdn}=3.79)$. As illustrated, an increase in the level of helping behavior for all employees was associated with a decrease in turnover intention. However, the line for females shows a larger negative slope, suggesting that this relationship was much more pronounced for females, as predicted in hypothesis 2. This effect was also evidenced through split regression analysis (Sharma, Durand \& Gur-Arie, 1981). The results revealed that, there was a stronger significant and negative relationship between helping behavior and turnover intention among females (beta $=-.26, \mathrm{p}<.001$ ) and a borderline significant negative relationship for males employees (beta $=-.11, \mathrm{p}=.05$ ).

\section{INSERT FIGURE 1}

\section{Discussion and Conclusions}

To summarize the results, we found that four of the five facets of OCB included in this analysis were found to be significantly related to turnover intention. The model also accounted for a meaningful amount of variance. These results are comparable to the findings of other industry by Chen et al., (1998) and Chen et al., (2002). The difference in this study was the inclusion of broader OCB dimensions and the moderating effect of gender. The possible short coming of common method variance can be ruled out since OCB dimensions were rated by managers whereas turnover intention were operationalized through self-report measured. As employees exhibited helping behavior, sportsmanship, patience and civic virtue, turnover intention was lower. It is worth noting that OCB dimensions that benefited the organization as a whole (sportsmanship and patience), appear to have more salience for respondents. However, the current finding that the conscientiousness was not related to turnover intention contrast with those of Chen et al., (1998) who found that conscientiousness significantly and negatively predicted turnover. These contrary findings may have to do with the differences in the measures of conscientiousness. In comparison to the measure used in this study, Chen at al., (1998) used a more general measure of conscientiousness such as 'is one of my most conscientious employees' and 'believes in giving an honest day's work for an honest day's pay'.

The first contribution of this study was the two way interaction between helping behavior and gender. The present result goes beyond providing empirical evident to the main effect of helping behavior, but also suggesting that the negative relationship between these variables is contingent on employees' gender. Second, in addition to supporting the existence of common OCB dimensions such as helping behavior, sportsmanship, civic virtue and conscientiousness in the Eastern culture, the present study identified a new dimension of OCB in the Malaysian context, that is patience which is probably unique to the Malaysian context and had not been explicitly measured and studied in the Western literature. Third, this study helps to bridge the gap in OCB literature in the context of Eastern culture. Although researchers have extensively studied organizational citizenship behavior (OCB) in the U.S. context, OCB measurement has received relatively limited attention in other contexts (Pascal, 2009). The forth contribution of the study is that it recasts the frequently studied concept of OCB. Previously, OCB has been viewed as a consequence of attitudinal and dispositional variables (Organ \& Ryan, 1995). This study took another direction by examining a possible outcome of OCB. The finding that $\mathrm{OCB}$ is related to turnover intention should complement the previous research findings that demonstrate that $\mathrm{OCB}$ are related to organizational effectiveness, because turnover intention is also related to organizational effectiveness. Fifth, the results from the present study indicate support for the notion of the theory of cognitive consistency. The applicability of this theory which was previously found across a variety of situation now is extended to the OCB and turnover intention linkages. Last but not least important, respondents for this study were selected from 
several departments, positions and more than 60 hotels. Such a sample increases the external generalizability of the results.

Whereas this study provides some insight into the importance of organizational citizenship behavior, several limitations of the research, both conceptual and methodological, are notable. First, limitation was generated by the use of Western measures. However, efforts were taken to reduce potential problems by back-translation, double-checking, and discussion of each questionnaire item with the hotel managers. New items were also developed to capture a broader citizenship behavior. As a result of this procedure, it is believed that the items were both appropriate and relevant to Malaysian respondents. Another limitation is that the results are based on non managers' employees, sample may not be generalized to managerial level positions in the hotel industry. Another issue is that other potentially important variables beyond facets of OCB especially job satisfaction and organizational commitment was not controlled in the model. The importance of OCB may have been reduced if these variables had been included. Finally, this study is based on cross-sectional data and thus, causality cannot be firmly established.

With these limitations in mind, the current results suggest several avenues of future research worthy of pursuit. To begin with, given the specific sample of the present study, expanded at replication to other forms of organization and industries would help the validation process. Second, the present research focuses on the relationship between OCB and turnover intention at the individual levels of analysis. An important avenue for future research is to explore this relationship at the group or organizational levels of analysis. It can be argued that the group with higher level of OCB may foster group cohesiveness and eventually decrease employees' turnover. This is consistent with suggestion by Schnake and Dumler (2003) that OCB occurs at the individual level, however it is OCB in the aggregate that impacts organizational effectiveness. Future research empirically testing this proposition would contribute to our understanding of the effect of aggregate OCB on turnover intention. The findings of the present study suggest that future research should also examine the effects of OCB on other forms of withdrawal behaviors such as absenteeism, lateness, tardiness and social loafing. Research of this nature could further our understanding of the relationship between OCB and a broader range of withdrawal behavior. Future research should also continue to examine the role of demographic factors as moderators. Study by Kuehn and Al-Busaidi (2002) for example found that level of OCB varied with age. His may suggest that OCB may interact with age in predicting withdrawal behavior. Additional research in this area seem not only warranted, but critical to advancing theory and practice regarding the field of OCB and withdrawal behavior.

The findings of the present study may convince practitioners of the importance of citizenship behavior. Hotel operators experiencing problems with work force turnover may be particularly interested in this study. Traditionally, turnover rates have been shown to be influenced by many factors such as availability of job, economic conditions, management style, opportunity to leave the present job and non-work factors. This study, however, provides initial evidence that withdrawal behaviors can also be predicted based on behavioral factor that is OCB. Offering competitive salaries and wide opportunity for promotion may be somewhat difficult for many hotels or may not be adequate to sustain good employees. However, hotels can promote loyalty by enhancing such things as citizenship behavior among employees. To encourage OCB among employees, managers may become role models by exhibiting high level of OCB. Podsakoff et al., (2000) indicated that "Supportive behavior on the part of the leader was strongly related to OCB and may underlie the effects of perceived organizational support on OCB" (p. 532). Additionally, hotel management should also look into employees' job satisfaction as well as commitment. On the human resource side, several steps are possible such as selecting job candidate which is based on their level of organizational citizenship behavior, improve policies and procedures concerning performance evaluation in such a way to include certain dimensions of citizenship behavior, and hire employees with high OCB by determining whether applicant have performed beyond minimum standard in their previous working experience or during schooling.

\section{References}

Aiken, L.S., \& West, S.G. (1991). Multiple regression: Testing and interpreting interactions. Newbury Park, CA: Sage Publication.

Ajzen, I., \& Fishbein, M. (1980). Understanding attitudes and predicting social behavior. Englewood Cliffs, New Jersey: Prentice-Hall.

Angle, H., \& Perry, J. (1981). An empirical assessment of organizational commitment and organizational effectiveness. Administrative Science Quarterly, 26, 1-14.

Arnold, H.J., \& Feldman, D.C. (1982). A multivariate analysis of the determinants of job turnover. Journal of Applied Psychology, 67, 350-360.

Bateman, T.S., \& Organ, D.W. (1983). Job satisfaction and the good soldier: The relationship between affect and employee citizenship. Academy of Management Journal, 26, 587-595.

Boshoff, C., \& Mels, G. (2000). The impact of multiple commitments on intentions to resign: An empirical assessment. British Journal of Management, 11, 255-273. 
Chaudhury, M., \& Ng, I. (1992). Absenteeism predictors: Least squares, rank regression, and model selection results. Canadian Journal of Economic, XXV, 615-635.

Chen, X.P., Hui, C., \& Sego, D.J. (1998). The role of organizational citizenship behavior in turnover: Conceptualization and preliminary tests of key hypothesis. Journal of Applied Psychology, 83, 922-931.

Coon, D. (1983). Introduction to psychology: Exploration and application. Minnesota: West Publishing Co.

Cotton, J.L., \& Tuttle, J.M. (1986). Employee turnover: A meta-analysis and review with implications for research. Academy of Management Review, 11, 55-70.

Eagly, A.H. (1987). Sex differences in social behavior: A social-role interpretation. Hillsdale, NJ: Erlbaum:

Farh, J.L., Earley, P.C., \& Lin, S.C. (1997). Impetus for action: A cultural analysis of justice and organizational citizenship behavior in Chinese society. Administrative Science Quarterly, 42, 421-444.

Faulkner, G., \& Reeves, C. (2000). Primary school students teachers' physical self-perceptions and attitudes toward teaching psysical education. Journal of Teaching Physical Education, 19, 311-324.

Green, T.D. \& Holeman, S. (2004). Athletes' attributions for team performance: A theretical test across sports and genders. Social Behavior and Personality, 32,199-206.

Hair, J.F. Jr., Anderson, R.E., Tatham, R.L., \& Black, W.C. (1998). Multivariate data analysis (5th ed.). New Jersey: Prentice Hall.

Kidder, D., \& Parks, J.M. (2001). The good soldier: Who is s(he)? Journal of Organizational Behavior, 22, 939-955.

Koh, H.C., \& Goh, C.T. (1995). An analysis of the factors affecting the turnover intention of non-managerial clerical staff: A Singapore study. The International Journal of Human Resource Management, 6, 103-125.

Konrad, A.M., Ritchie, J.E., Lieb, P., \& Corrigall, E. (2000). Sex differences and similarities in job attribute preferences: A meta-analysis. Psychological Bulletin, 126, 593-641.

Koys, D.J. (2003). How the achievement of human resources goals drives restaurant performance. Cornell Hotel and Restaurant Administration Quarterly, 44, 17-23.

Kuehn, K.W., \& Al-Busaidi, Y. (2002). Citizenship behavior in a non-western context: An examination of the role of satisfaction, commitment and job characteristics on self-reported organizational citizenship behavior. International Journal of Commerce \& Management, 12, 107-125.

LePine, J.A., Erez, A., \& Johnson, D.E. (2002). The nature and dimensionality of OCB: A critical review and meta-analysis. Journal of Applied Psychology, 87, 52-65.

Lovel, S.E., Anton, J., Mason, C., \& Davidson, A. (1999). Does gender affect the link between organizational citizenship behavior and performance evaluation, Sex Roles, 41, 469-479.

Moorman, R.H., \& Blakely, G.L. (1995). Individualism and collectivism as an individual difference predictor of organizational citizenship behavior. Journal of Organizational Behavior, 16, 127-142.

Morrison, E.W. (1994). Role definitions and organizational citizenship behavior: The importance of the employee's perspective. Academy of Management Journal, 37, 1543-1567.

Niehoff, B.P., \& Moorman, R.H. (1993). Justice as a mediator of the relationship between methods of monitoring and organizational citizenship behavior. Academy of Management Journal, 36, 527-556.

Nunnally, J.C. (1978). Psychometric theory. New York: McGraw-Hill.

Organ, D.W. (1988). Organizational Citizenship Behavior: The Good Soldier Syndrome.Lexington, MA: Lexington Books.

Organ, D.W., \& Ryan, K. (1995). A meta-analytic review of attitudinal and dispositional predictors of organizational citizenship behavior. Personnel Psychology, 48, 775-802.

Pascal, P. (2009). Assessing organizational citizenship behavior in the French context: Evidence for the four-dimensional model. Journal of Psychology, 143, 133-146.

Peloza, J., Hudson, S., \& Hassay, D.N. (2009). The marketing of employee volunteerism. Journal of Business Ethics, $85,371-387$.

Pelted, L.H., \& Xin, K.R. (1999). Down and out: An investigation of the relationship between mood and employee withdrawal behavior. Journal of Management, 25, 875-896.

Podsakoff, P.M., \& MacKenzie, S.B. (1994). Organizational citizenship behaviors and sales unit effectiveness. Journal of Marketing Research, 31, 351-364. 
Podsakoff, P.M., Ahearne, M., \& MacKenzie, S.B. (1997). Organizational citizenship behavior and the quantity and quality of work group performance. Journal of Applied Psychology, 82, 262-270.

Podsakoff, P.M., MacKenzie, S.B., Paine, J.B., \& Bachrach, D.G. (2000). Organizational citizenship behavior: A critical review of the theoretical and empirical literature and suggestions for future research. Journal of Management, 26, 513-563.

Schnake, M.E., \& Dumler, M.P. (2003). Levels of measurement and analysis issues in organizational citizenship behavior research. Journal of Occupational and Organizational Psychology, 76, 283-301.

Sharma, S., Durand, R.M., \& Gur-Arie, O. (1981). Identification and analysis of moderator variables. Journal of Marketing Research, XVIII, 291-300.

Shaw, D.J., John, E.D., Jenkins, .D. Jr., \& Nina, G. (1998). An organization-level analysis of voluntary and involuntary turnover. Academy of Management Journal, 41, 511-525.

Shengming, T., \& Jiping, Z. (1997). Profile of college examination cheaters. College Student Journal, 31, $340-347$.

Van Scooter, J.R. (2000). Relationships of task performance and contextual performance with turnover, job satisfaction, and affective commitment. Human Resource Management Review, 10, 79-96.

Ward, D.A. (1986). Self-esteem and dishonest behavior revisited. Journal of Social Psychology, 126, 709-713.

Weisberg, J., \& Kirschenbaum, A. (1993). Gender and turnover: A reexamination of the impact of sex on intent and actual job changes. Human Relations, 46, 487-499.

Williams, L.J., \& Anderson, S.E. (1991). Job satisfaction and organizational commitment as predictors of organizational citizenship and in-role behaviors, Journal of Management, 17, 601-617.

Table 1. Summary of Factor Analysis for Manager Ratings OCB Items

\begin{tabular}{|c|c|c|c|c|c|}
\hline \multirow[b]{2}{*}{ Organizational Citizenship Behaviour Items } & \multicolumn{5}{|c|}{ Component } \\
\hline & 1 & 2 & 3 & 4 & 5 \\
\hline $\begin{array}{l}\text { 1. Consults you or other individuals who might be affected by his/her } \\
\text { actions or decisions. }\end{array}$ & .716 & .052 & .201 & .007 & .184 \\
\hline 2. Helps others who have heavy work loads & .688 & .166 & .091 & .325 & .062 \\
\hline $\begin{array}{l}\text { 3. Willingly gives his/her time to help others who have work-related } \\
\text { problems. }\end{array}$ & .680 & .181 & .071 & .300 & .128 \\
\hline 4. Informs you before taking any important actions. & .677 & .163 & .349 & -.020 & .058 \\
\hline 5. Takes steps to prevent problems with other workers. & .673 & .324 & .243 & .143 & .157 \\
\hline 6. Helps others who have been absent. & .664 & .143 & .111 & .333 & .079 \\
\hline 7. Is always willing to cooperate with others to get a job done. & .650 & .411 & .185 & .211 & .119 \\
\hline $\begin{array}{l}\text { 8. Is willing to share his/her knowledge and expertise to help others } \\
\text { improve their work performance. }\end{array}$ & .640 & .348 & .143 & .205 & .151 \\
\hline 9. Helps new people to get accustomed to work environment. & .629 & .242 & .160 & .309 & .246 \\
\hline 10. Help others with demanding work assignment. & .610 & .202 & .155 & .243 & .263 \\
\hline 11. Does not abuse the rights of others. & .608 & .277 & .269 & -.031 & .131 \\
\hline 12. Helps train new people even though it is not required. & .605 & .222 & .170 & .297 & .243 \\
\hline 13. Pay attention to hotel memos or announcements. & .567 & .228 & .318 & .058 & .297 \\
\hline 14. Concerned with the effects of his/her actions or decision on others. & .552 & .228 & .171 & .192 & .142 \\
\hline 15. Tends to make a "mountain out of molehills"(R) & .124 & .805 & .119 & .204 & .135 \\
\hline 16. Always finds faults with what the hotel is doing $(R)$. & .192 & .760 & .147 & .173 & .128 \\
\hline
\end{tabular}


17. Always focuses on what's wrong with his/her situation, rather than with the positive side of it $(\mathrm{R})$

18. Consumes a lot of time complaining about trivial matters.(R )

19. Is always neglectful in coordinating his/her work with others. (R )

20. Puts in less effort than other members of his/her work group. (R )

21. Never takes long lunches.

22. Does not take extra breaks.

23. Is always punctual at work.

24. Always maintain a tidy work area.

25. Is the kind of person who can tolerate occasional inconvenience at work.

26. Does not feel disappointed if others disapprove of his/her ideas or suggestions.

27. Is the kind of person who is willing to face any difficulty with the organization.

28. Attend and participates in formal and informal hotel meetings.

29. Attends functions that are not required, but help the hotel's image.

30. 'Keep up' with developments in the hotel.

\begin{tabular}{|c|c|c|c|c|}
\hline .326 & .707 & .221 & -.006 & .091 \\
\hline .331 & .673 & .213 & .141 & .053 \\
\hline .351 & .655 & .068 & .098 & .072 \\
\hline .113 & .649 & .091 & .327 & .204 \\
\hline .169 & .151 & .844 & .185 & .124 \\
\hline .184 & .176 & .838 & .179 & .071 \\
\hline .383 & .163 & .590 & .037 & .061 \\
\hline .386 & .172 & .546 & .085 & .089 \\
\hline .294 & .217 & .090 & .730 & .131 \\
\hline .169 & .174 & .215 & .645 & .108 \\
\hline .332 & .272 & .105 & .638 & .263 \\
\hline .210 & .232 & .104 & .143 & .818 \\
\hline .260 & .074 & .096 & .165 & .817 \\
\hline .434 & .304 & .141 & .241 & .530 \\
\hline
\end{tabular}

Kaiser-Meyer-Olkin(KMO)=.952; Bartlett's Test of Sphericity-Chi Square=10233.234; Degree of freedom=435; Sig. $=.000$

Table 2. Intercorrelation between study variables

\begin{tabular}{|l|c|c|c|c|c|c|c|c|c|c|}
\hline Variable & Mean & SD & 1 & 2 & 3 & 4 & 5 & 6 & 7 & 8 \\
\hline 1. Gender & - & - & & & & & & & & \\
\hline 2. OCB & 3.59 & .59 & .05 & - & & & & & & \\
\hline $3 . \mathrm{HB}$ & 3.66 & .64 & .08 & $.95^{* *}$ & $(.94)$ & & & & & \\
\hline $4 . \mathrm{SM}$ & 3.57 & .81 & -.01 & $.82^{* *}$ & $.66^{* *}$ & $(.88)$ & & & & \\
\hline $5 . \mathrm{CT}$ & 3.66 & .72 & -.04 & $.72^{* *}$ & $.63^{* *}$ & $.50^{* *}$ & $(.82)$ & & & \\
\hline $6 . \mathrm{PT}$ & 3.45 & .73 & .06 & $.74^{* *}$ & $.64^{* *}$ & $.56^{* *}$ & $.44^{* *}$ & $(.76)$ & & \\
\hline $7 . \mathrm{CV}$ & 3.32 & .75 & .06 & $.72^{* *}$ & $.64 * *$ & $.51^{* *}$ & $.41^{* *}$ & $.55^{* *}$ & $(.81)$ & \\
\hline $8 . \mathrm{TI}$ & 2.48 & .94 & -.08 & $-.44^{* *}$ & $-.38^{* *}$ & $-.42^{* *}$ & $-.23^{* *}$ & $-.43^{* *}$ & $-.34 * *$ & $(.75)$ \\
\hline
\end{tabular}

Note: $\mathrm{N}=557$ for turnover intention; $\mathrm{N}=522$ for self-reported absenteeism; ${ }^{*} \mathrm{p}<.05 ; * * \mathrm{p}<.01$

No alpha coefficient exist for self-reported absenteeism because it consisted of only one question. Reliabilities on diagonal in parentheses

OCB - OCB Composite Score; HB - Helping Behavior; SM - Sportsmanship; CT - Conscientiousness; PT - Patience; CV - Civic Virtue; TI - Turnover Intention. 
Table 3. Summary of Multiple Regression Analysis for OCB on Turnover Intention

\begin{tabular}{|c|c|c|c|c|}
\hline $\begin{array}{l}\text { Variables entered in the } \\
\text { equation }\end{array}$ & Change in $\mathrm{R}^{2}(\%)$ & Sig. of F (Overall) & $\beta$ & $\begin{array}{c}\text { Sig. of F (for } \\
\text { individual variance) }\end{array}$ \\
\hline \multicolumn{5}{|l|}{ Step 1} \\
\hline Helping Behavior & & & -.21 & .00 \\
\hline Sportsmanship & & & -.31 & .00 \\
\hline Conscientiousness & & & -.05 & ns \\
\hline Patience & & & -.29 & .00 \\
\hline Civic virtue & .25 & .00 & -.15 & .00 \\
\hline \multicolumn{5}{|l|}{ Step 2} \\
\hline Gender & .3 & ns & .05 & ns \\
\hline \multicolumn{5}{|l|}{ Step 3} \\
\hline Helping Behavior x Gender & & & .12 & .02 \\
\hline Sportsmanship x Gender & & & -.00 & ns \\
\hline Conscientiousness x Gender & & & .07 & ns \\
\hline Patience $\mathrm{x}$ Gender & & & .01 & ns \\
\hline Civic Virtue $x$ Gender & .8 & .02 & -.06 & ns \\
\hline
\end{tabular}

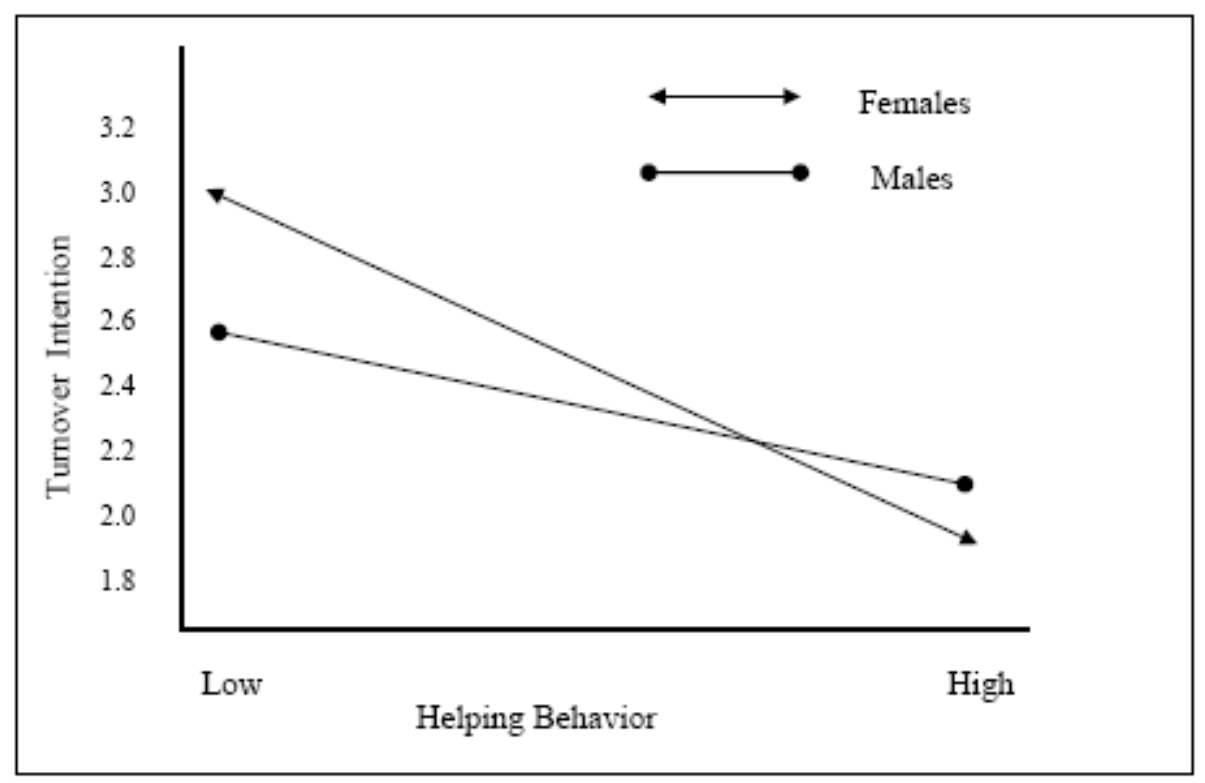

Figure 1. The effect of gender on the helping behavior - tumover intention relation. 